\title{
钯催化苯乙烯类分子胺氟化反应研究
}

\author{
朱海涛＼cjkstart刘国生* \\ (金属有机化学国家重点实验室 中国科学院上海有机化学研究所 上海 200032)
}

\begin{abstract}
摘要 报道了烯烃分子间的氧化双官能团化反应，用金属钯作为金属催化剂，三价碘为氧化剂，氟化银为氟源，磺酰 胺类为亲核试剂，实现了苯乙烯的分子间胺氟化反应，得到 $\alpha-\mathrm{F}$ 代苯乙胺类化合物; 反应是经过烯烃的反马氏氮钯化得 到碳钯键，再经过三价碘氧化成高价钯的中间体来形成 $\mathrm{C}-\mathrm{F}$ 键，在分子中的特定位置引入氟原子. 该反应的一个特点 是选择性地得到反马氏胺氟产物.
\end{abstract}

关键词 钯; 胺氟化; 反马氏胺钯化; 苯乙烯; 烯烃双官能团化

\section{Palladium-Catalyzed Oxidative Aminofluorination of Styrenes}

\author{
Zhu, Haitao Liu, Guosheng* \\ (State Key Laboratory of Organometallic Chemistry, Shanghai Institute of Organic Chemistry, Chinese Academy of Sciences, \\ Shanghai 200032)
}

\begin{abstract}
A novel palladium-catalyzed intermolecular aminofluorination of styrenes has been developed, using silver fluoride as the fluorine source, palladium diacetate as metal catalyst, and acetonitrile as solvent at room temperature. As regard to the mechanism, we proposed that the anti-Markovnikov aminopalladation was involved in the construction of $\mathrm{C}-\mathrm{N}$ bond. This selectivity of nucleophilic palladation of styrenes is different from that reported before. In order to verify our proposed mechanism, we conducted the competition experiments using styrenes containing different functional groups. The results are consistent with our analysis. We belive that the $\mathrm{C}-\mathrm{F}$ bond is formed after the $\mathrm{Pd}(\mathrm{II})-\mathrm{C}$ is oxidized to $\mathrm{Pd}(\mathrm{IV}$ )-C. Namely, the high oxidative state palladium is involved in catalytic cycle. In all, this transformation represents a novel strategy to synthesize a variety of vicinal fluoroamine derivatives.

Keywords palladium; aminofluorination; anti-Markovnikov; styrene
\end{abstract}

\section{Introduction}

Molecules bearing a fluorine moiety exhibit many significantly improved properties, including solubility, bioactivity and metabolic stability, therefore are of great importance in pharmaceuticals. ${ }^{[1]}$ So new methods for the synthesis of fluorinated molecules are in demand, but only few effective approaches are available for the direct construction of $\mathrm{C}-\mathrm{F}$ bond. ${ }^{[2,3]}$

Among the strategies of $\mathrm{C}-\mathrm{N}$ bond formation, the synthesis of amine derivatives via intermolecular amination is rather attractive. ${ }^{[4]}$ Palladium-catalyzed methods for the synthesis of enamide derivatives through intermolecular oxidative amination of unactivated olefins have been reported recently. ${ }^{[5,6]}$ We are particularly interested in developing transition metal-catalyzed fluorination of olefins to achieve $\mathrm{C}-\mathrm{F}$ bond formation under mild conditions. ${ }^{[7]}$ Very recently, our group has reported the $\mathrm{Pd}(\mathrm{OAc})_{2} /$ BC(bathocuproine)-catalyzed intermolecular aminofluorination of vinylarenes, where the fluoropalladation of styrenes was proposed as the key step in the $\mathrm{C}-\mathrm{F}$ bond formation (Scheme 1a). ${ }^{[8]}$ Herein, we describe a novel palladium-catalyzed intermolecular oxidative aminofluorination of styrenes, which is initiated by antiMarkovnikov aminopalladation of styrenes, and followed by fluorination of $\mathrm{C}_{\mathrm{sp}^{3}}-\mathrm{Pd}$ bond by $\mathrm{AgF} / \mathrm{PhI}(\mathrm{OPiv})_{2}$ to afford aminofluorination product (Scheme $1 \mathrm{~b}$ ). It is remarkable that this reaction affords aminofluorination product with complementary regioselectivity of our previous catalytic system.

\section{Results and discussion}

We have reported a $\mathrm{Pd}(\mathrm{OAc})_{2}$-catalyzed intramolecular aminofluorination of unactivated alkenes, where the $\mathrm{C}_{\mathrm{sp} 3}$ $\mathrm{Pd}$ bond generated via intramolecular aminopalladation was oxidatively cleaved by $\mathrm{PhI}(\mathrm{OPiv})_{2} / \mathrm{AgF}$ resulting in $\mathrm{C}-\mathrm{F}$ bond formation. ${ }^{[9]}$ We postulate that the intermolecular reaction might provide an efficient strategy to synthesize a variety of vicinal aminofluoride compounds from simple alkenes. Based on this hypothesis, our initial studies focused on the reaction of styrene 1a and $N$-methyl tosylamide 2 a with $\mathrm{Pd}(\mathrm{OAc})_{2}$ as catalyst. We were delighted to find that a significant amount of aminofluorination

\footnotetext{
* E-mail: gliu@mail.sioc.ac.cn; Tel.: 0086-021-54925346; Fax: 0086-021-64166128.

Received October 29, 2012; published November 12, 2012.

Supporting information for this article is available free of charge via the Internet at http://sioc-journal.cn.

Project supported by the 973 Program of China (No. 2009CB825300), the National Natural Science Foundation of China (Nos. 20972175, 20923005), and the Science and Technology Commission of the Shanghai Municipality (No. 11JC1415000).

项目受科技部 973 (No. 2009CB825300)、国家自然科学基金(Nos. 0972175, 20923005)和上海市科委(No. 11JC1415000)资助.
} 
(a) via fluoropalladation, see ref. [8]

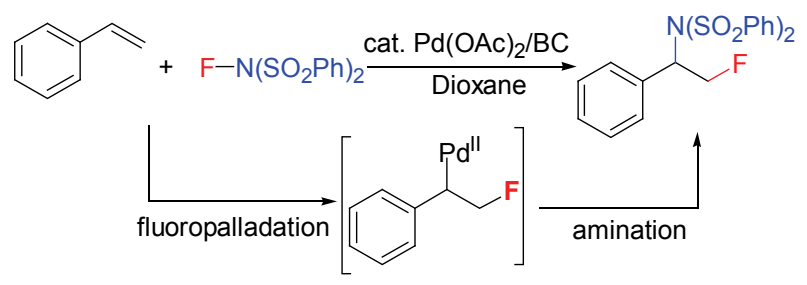

(b) via aminopalladation, this work

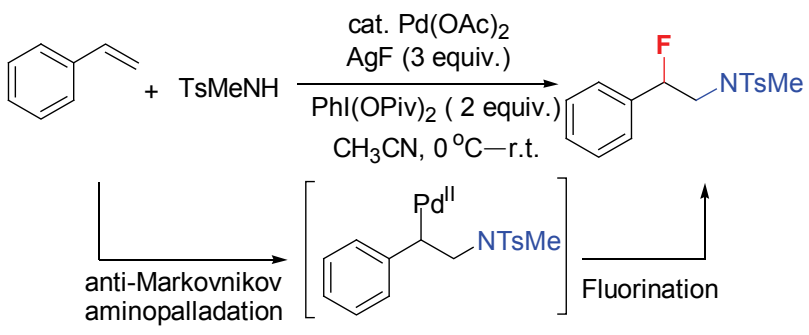

Scheme 1 Pd-catalyzed aminofluorination of styrenes.

product 3a, as well as a small amount of aminoacetoxylation product $\mathbf{5 a}$, were observed when the reaction was treated in the presence of $\mathrm{AgF}$ and $\mathrm{PhI}(\mathrm{OPiv})_{2}$. A survey of divalent palladium salt revealed that $\mathrm{PdCl}_{2}\left(\mathrm{CH}_{3} \mathrm{CN}\right)_{2}$ afforded the best results, and no reaction occurred in the absence of Pd catalyst (Table 1, Entries 1-6). The following screening of inorganic fluoride salts showed that AgF was the only effective fluoride salt (Table 1, Entries 7-9). ${ }^{[10]}$ Interestingly, the aminofluorination was also achieved in the presence of $\mathrm{Et}_{3} \mathrm{~N} \cdot 3 \mathrm{HF}$, albeit in lower yield (Table 1, Entry 10). Further investigation of oxidants indicated that hypervalent iodine was only effective type of oxidant for the reaction, among which $\mathrm{PhI}(\mathrm{OPiv})_{2}$ was the best (Table 1, Entries 4, 10-14). The yield of aminofluorination product 3a was improved by increasing the amount of styrene to 10 equivalents (Table 1, Entry 15). Finally, lower reaction temperature was found to be beneficial to the reaction yield (Table 1, Entry 16). Unfortunately, the reaction yield was not improved any more by further optimization, either addition of bisdentate-nitrogen ligands or base. It is worth noting that the reaction exhibits an excellent regioselectivity, which is complementary to the normal oxidative amination of styrene. ${ }^{[\mathrm{ba}, 6 \mathrm{c}]}$

Under the optimized reaction conditions, the scope of amine nucleophiles was investigated. As shown in Eq. 1, sulfonylamide was proved to be an efficient nucleophile, whereas other amides, such as acetamide, phathalimide or oxazolinone, were not compatible. Further studies revealed that electron-rich sulfonylamides $(\mathbf{2 a}-\mathbf{2 c})$ exhibited higher activity than electron-deficient sulfonylamides (2d, $\mathbf{2 h})$. In addition, significant steric effect was observed in the reaction, as stereohindered nucleophiles $(\mathbf{2} \mathbf{e}-\mathbf{2 g})$ led to low yields.

The scope of alkenes was examined with a variety of styrenes under the optimized reaction conditions (Eq. 2). The reactions of $p$-tert-butyl and $p$-methylstyrene afforded 4b, $\mathbf{4 c}$ at $49 \%$ and $36 \%$ yields, respectively. The possible reason for lower yield was that the electron-rich styrenes (1b and 1c) easily underwent polymerization and resulted
Table 1 Screening results ${ }^{a}$

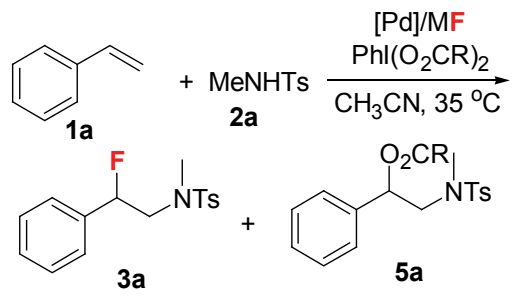

\begin{tabular}{|c|c|c|c|c|c|}
\hline \multirow{2}{*}{ Entry } & \multirow{2}{*}[\mathrm{Pd}]{} & \multirow{2}{*}{ MF } & \multirow{2}{*}[\mathrm{O}]{} & \multicolumn{2}{|c|}{ Yield $^{b} \%$} \\
\hline & & & & 3a & $5 \mathbf{a}$ \\
\hline 1 & $\mathrm{Pd}(\mathrm{OAc})_{2}$ & $\mathrm{AgF}$ & $\mathrm{PhI}(\mathrm{OPiv})_{2}$ & 38 & 14 \\
\hline 2 & $\mathrm{Pd}(\mathrm{OTFA})_{2}$ & $\mathrm{AgF}$ & $\mathrm{PhI}(\mathrm{OPiv})_{2}$ & 37 & 9 \\
\hline 3 & $\mathrm{PdCl}_{2}$ & $\mathrm{AgF}$ & $\mathrm{PhI}(\mathrm{OPiv})_{2}$ & 35 & 7 \\
\hline 4 & $\mathrm{PdCl}_{2}\left(\mathrm{CH}_{3} \mathrm{CN}\right)_{2}$ & $\mathrm{AgF}$ & $\mathrm{PhI}(\mathrm{OPiv})_{2}$ & 45 & 14 \\
\hline 5 & $\mathrm{Na}_{2} \mathrm{PdCl}_{4}$ & $\mathrm{AgF}$ & $\mathrm{PhI}(\mathrm{OPiv})_{2}$ & 14 & 8 \\
\hline 6 & - & $\mathrm{AgF}$ & $\mathrm{PhI}(\mathrm{OPiv})_{2}$ & 0 & 0 \\
\hline 7 & $\mathrm{PdCl}_{2}\left(\mathrm{CH}_{3} \mathrm{CN}\right)_{2}$ & $\mathrm{NaF}$ & $\mathrm{PhI}(\mathrm{OPiv})_{2}$ & 0 & 15 \\
\hline 8 & $\mathrm{PdCl}_{2}\left(\mathrm{CH}_{3} \mathrm{CN}\right)_{2}$ & $\mathrm{KF}$ & $\mathrm{PhI}(\mathrm{OPiv})_{2}$ & 0 & 30 \\
\hline 9 & $\mathrm{PdCl}_{2}\left(\mathrm{CH}_{3} \mathrm{CN}\right)_{2}$ & $\mathrm{CsF}$ & $\mathrm{PhI}(\mathrm{OPiv})_{2}$ & 0 & 5 \\
\hline 10 & $\mathrm{PdCl}_{2}\left(\mathrm{CH}_{3} \mathrm{CN}\right)_{2}$ & $\mathrm{Et}_{3} \mathrm{~N} \cdot 3 \mathrm{HF}$ & $\mathrm{PhI}(\mathrm{OPiv})_{2}$ & 22 & 4 \\
\hline 11 & $\mathrm{PdCl}_{2}\left(\mathrm{CH}_{3} \mathrm{CN}\right)_{2}$ & $\mathrm{AgF}$ & $\mathrm{PhI}(\mathrm{OAc})_{2}$ & 42 & 15 \\
\hline 12 & $\mathrm{PdCl}_{2}\left(\mathrm{CH}_{3} \mathrm{CN}\right)_{2}$ & $\mathrm{AgF}$ & $\mathrm{PhI}(\mathrm{OAdm})_{2}$ & 33 & 4 \\
\hline 13 & $\mathrm{PdCl}_{2}\left(\mathrm{CH}_{3} \mathrm{CN}\right)_{2}$ & $\mathrm{AgF}$ & $\mathrm{PhI}(\mathrm{OBz})_{2}$ & 27 & 8 \\
\hline 14 & $\mathrm{PdCl}_{2}\left(\mathrm{CH}_{3} \mathrm{CN}\right)_{2}$ & $\mathrm{AgF}$ & $\mathrm{PhIO}$ & 0 & 0 \\
\hline $15^{c}$ & $\mathrm{PdCl}_{2}\left(\mathrm{CH}_{3} \mathrm{CN}\right)_{2}$ & $\mathrm{AgF}$ & $\mathrm{PhI}(\mathrm{OPiv})_{2}$ & 54 & 9 \\
\hline $16^{c, d}$ & ${ }^{t} \mathrm{PdCl}_{2}\left(\mathrm{CH}_{3} \mathrm{CN}\right)_{2}$ & $\mathrm{AgF}$ & $\mathrm{PhI}(\mathrm{OPiv})_{2}$ & 60 & 5 \\
\hline
\end{tabular}

${ }^{a}$ Reaction condition: $\mathrm{Pd}$ salt (10 mol\%), MF (2.5 equiv.), $\mathrm{PhI}\left(\mathrm{O}_{2} \mathrm{CR}\right)_{2}$ (2 equiv.), 2a (0.2 mmol), 1a (1 mmol), $\mathrm{CH}_{3} \mathrm{CN}(0.5 \mathrm{~mL}), 35{ }^{\circ} \mathrm{C}, 24 \mathrm{~h} ;{ }^{b} \mathrm{NMR}$ yield with $N, N$-dimethyltrifluoroacetamide as internal standard, ${ }^{19} \mathrm{~F}$ NMR for 3a and ${ }^{1} \mathrm{H}$ NMR for 5a; ${ }^{c}$ 1a $(2 \mathrm{mmol}), \operatorname{AgF}$ (3 equiv.); ${ }^{d}$ the reaction was carried out at $0{ }^{\circ} \mathrm{C}$ for $24 \mathrm{~h}$ then $35{ }^{\circ} \mathrm{C}$ for $8 \mathrm{~h}$.

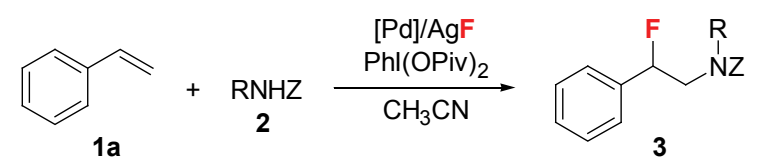<smiles>CNS(=O)(=O)c1ccc(C)cc1</smiles>

2a $61 \%$<smiles>CNS(=O)(=O)c1ccccc1</smiles><smiles>CNS(=O)(=O)c1ccc(OC(=O)[O-])cc1</smiles><smiles>CNS(=O)(=O)c1ccc([N+](=O)[O-])cc1</smiles><smiles>Cc1ccc(S(=O)(=O)Nc2ccccc2)cc1</smiles>

$2 \mathrm{~g} 14 \%$<smiles>CNS(=O)(=O)c1c(C)cc(C)cc1C</smiles>

2e $35 \%$<smiles>CONS(=O)(=O)c1ccc(C)cc1</smiles><smiles>CCNS(=O)(=O)c1ccc(C)cc1</smiles>

Reaction conditions: styrene (10 equiv.), nucleophile $(0.2 \mathrm{mmol})$ $\mathrm{AgF}$ (3 equiv.), $\mathrm{Phl}(\mathrm{OPiv})_{2}$ (2 equiv.), $\mathrm{PdCl}_{2}\left(\mathrm{CH}_{3} \mathrm{CN}\right)_{2}(10 \mathrm{~mol} \%)$, $\mathrm{CH}_{3} \mathrm{CN}(0.5 \mathrm{~mL}), 0{ }^{\circ} \mathrm{C}$ for $24 \mathrm{~h}$, and $35{ }^{\circ} \mathrm{C}$ for $8 \mathrm{~h}$, isolated yield 


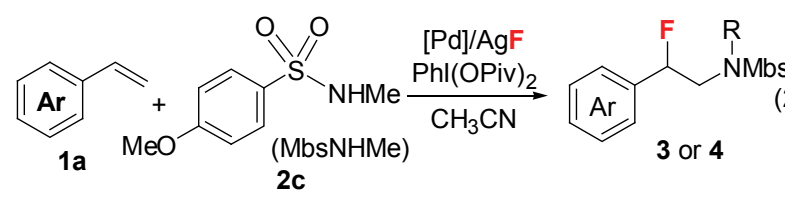<smiles>[R]N(C)CC(F)c1ccccc1</smiles><smiles>[R]NCC(F)c1ccc(C(F)CN([R])S(C)(=O)=O)cc1</smiles>

4a (3c) $64 \%$<smiles>[R]N([R5])CC(F)c1ccc(OC(C)=O)cc1</smiles><smiles>[R]NCC(F)c1ccc(F)cc1</smiles><smiles>[R]N([R16])CC(F)c1ccc(Cl)cc1</smiles><smiles>[R]NCC(F)c1ccc(Br)cc1</smiles>

4g $58 \%$<smiles>[R]N(C)CC(F)c1ccccc1</smiles><smiles>[B]Br</smiles>
4h $28 \%$<smiles>COC(C)=O</smiles><smiles>[R]NCC(F)c1ccc(C(=O)O)cc1</smiles>

4i $41 \%$<smiles>[R]NCC(F)c1ccc([N+](=O)[O-])cc1</smiles>

4j $19 \%$<smiles>[R]N(C)CC(C)(F)c1ccccc1</smiles>

4k $0 \%$

Reaction conditions: styrene (10 equiv.), nucleophile $(0.2 \mathrm{mmol})$, $\mathrm{AgF}$ (3 equiv.), $\mathrm{Phl}(\mathrm{OPiv})_{2}$ (2 equiv.), $\mathrm{PdCl}_{2}\left(\mathrm{CH}_{3} \mathrm{CN}\right)_{2}(10 \mathrm{~mol} \%)$, $\mathrm{CH}_{3} \mathrm{CN}(0.5 \mathrm{~mL}), 0{ }^{\circ} \mathrm{C}$ for $24 \mathrm{~h}$, and $35{ }^{\circ} \mathrm{C}$ for $8 \mathrm{~h}$, isolated yield

in viscous solution. Substrate 1d gave a moderate yield. Styrenes $\mathbf{1 e}-\mathbf{1 g}$ with halide substitution in benzene ring underwent intermolecular aminofluorination to afford the corresponding products $\mathbf{4 e - 4}$ in moderate yields, and there was no obvious difference in reactivity. Steric effect was observed in the case of $o$-bromostyrene $(\mathbf{1 h})$. The reaction of substrates $(\mathbf{1 i}-\mathbf{1 j})$ with electron-withdrawing groups, such as ester and nitro, exhibited slightly lower reactivity. The 1,1-disubstituted styrene (1k) afforded no desired product, which was likely caused by steric effect. Above results showed that this transformation exhibits a significantly narrow substrate scope, which needs to improve in future study.

During our optimization, trace amount of enamide 6a $(<5 \%)$ was also observed in addition to the aminofluorination product 3a and aminocarboxylation product $\mathbf{5 a}$. This observation indicated that the reaction involved an anti-Markovnikov aminopalladation of styrene to afford Pd(II) intermediate I, which was then converted into product 3 via subsequent oxidative fluorination of $\mathrm{C}-\mathrm{Pd}$ bond (Scheme 2). One possible origin for the anti-Markovnikov aminopalladation is that the $\mathrm{Pd}(\mathrm{II})$ intermediate I may be stabilized by formation of a $\pi$-benzylic structure $\mathbf{I}^{\text {. }}$. ${ }^{[1]}$

In order to address the observed regiochemistry, competition experiments were conducted with styrene substrates containing different functional groups. The observed value $(-0.38)$ is consistent with the aforementioned analysis (Figure 1).

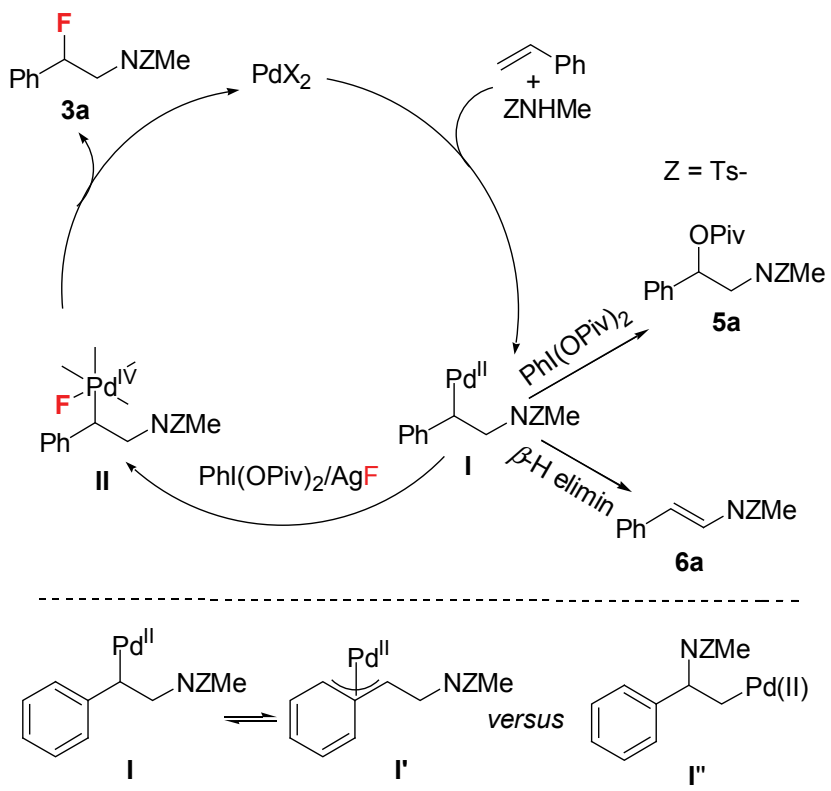

Scheme 2 Proposed mechanism for the palladium-catalyzed aminofluorination
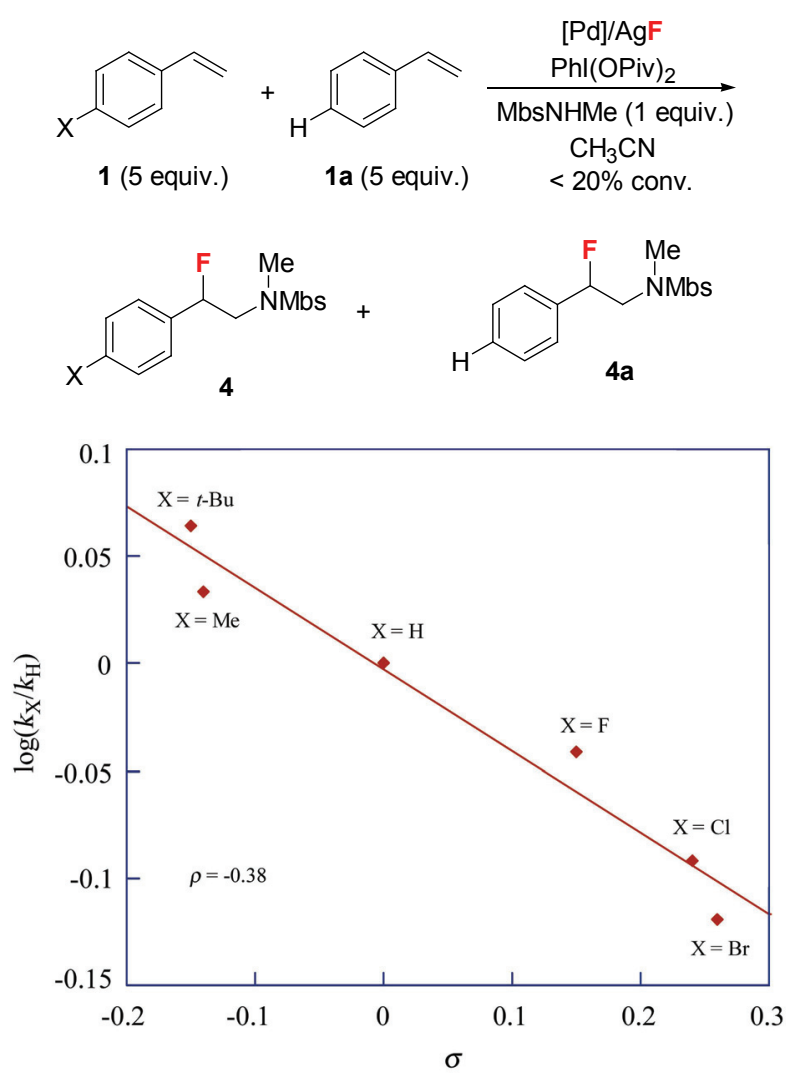

Figure 1 Hammett studies of styrenes with different substitution

\section{Conclusion}

We have developed a novel palladium-catalyzed intermolecular aminofluorination of styrenes. Anti-Markovnikov aminopalladation was involved to construct the $\mathrm{C}-$ $\mathrm{Pd}$ bond, and the subsequent oxidative fluorination of the 
$\mathrm{C}_{\mathrm{sp}^{3}}-\mathrm{Pd}$ bond afford the $\mathrm{C}-\mathrm{F}$ bond. This transformation represents a novel strategy to synthesize a variety of vicinal fluoroamine derivatives.

\section{References}

[1] (a) Welch, J. T.; Eswarakrishman, S. Fluorine in Bioorganic Chemistry, Wiley, New York, 1991; (b) Banks, R. E.; Smart, B. E.; Tatlow, J. C. Organofluorine Chemistry, Principles and Commercial Application, Plenum Press, New York, 1994.

[2] For reviews on fluorination of organic compounds, see (a) Nyffeler, P. T.; Duron, S. G.; Burkart, M. D.; Vincent, S. P.; Wong, C. H. Angew. Chem. Int. Ed. 2005, 44, 192; (b) Shimizu, M.; Hiyama, T. Angew. Chem. Int. Ed. 2005, 44, 214; (c) Pihko, P. M. Angew. Chem. Int. Ed. 2006, 45, 544; (d) Appayee, C.; Brenner-Moyer, S. E. Org. Lett. 2010, 12, 3357.

[3] (a) Smoekh, L.; Shanzer, A. J. Am. Chem. Soc. 1982, 104, 5836; (b) Philips, A. J.; Uto, Y.; Wipf, P.; Reno, M. J.; Williams, D. R. Org. Lett. 2000, 2, 1165; (c) Li, Y.; Ni, C.; Liu, J.; Zhang, L.; Zheng, J.; Zhu, L.; Hu, J. Org. Lett. 2006, 8, 1693; (d) Anbarasan, P.; Neumann, H.; Beller, M. Angew. Chem. Int. Ed. 2010, 49, 2219; (e) Wilson, D. A. US 4339070, 1983 [Chem. Abstr. 1983, 99, 138839].

[4] For some reviews, see: (a) Müller, T. E.; Beller, M. Chem. Rev. 1998, 98, 675; (b) Brunet, J. J.; Togni, A.; Grützmacher, D. H. Catalytic Heterofunctionalization, Wiley-VCH, New York, 2001, pp. 91 141; (c) Eds.: Hong, S.; Marks, T. J. Acc. Chem. Res. 2004, 37, 673; (d) Hartwig, J. F. Pure Appl. Chem. 2004, 76, 507.

[5] For reviews that describe oxidative amination reaction, see: (a) Beccalli, E. M.; Broggini, G.; Marttinelli, M.; Sottocornola, S. Chem. Rev. 2007, 107, 5318; (b) Stahl, S. S. Angew. Chem. Int. Ed. 2004, 43, 3400; (c) Kotov, V.; Scarborough, C. C.; Stahl, S. S. Inorg. Chem. 2007, 46, 1910; (d) McDonald, R. I.; Liu, G. S.; Stahl, S. S. Chem. Rev. 2011, 111, 2981.
[6] For some examples of intermolecular oxidative amination of alkenes, see: (a) Timokhin, V. I.; Anastasi, N. R.; Stahl, S. S. J. Am. Chem. Soc. 2003, 125, 12996; (b) Brice, J. L.; Harang, J. E.; Timokhin, V. I.; Anastasi, N. R.; Stahl, S. S. J. Am. Chem. Soc. 2005 127, 2868; (c) Timokhin, V. I.; Stahl, S. S. J. Am. Chem. Soc. 2005, 127,17888 .

[7] For recent reviews on transition metal-catalyzed C-F bond formation, see: (a) Brown, J. M.; Gouvernuer, V. Angew. Chem. Int. Ed. 2009, 48, 8610; (b) Grushin, V. V. Acc. Chem. Res. 2010, 43, 160; (c) Furuya, T.; Klein, J. E. M. N.; Ritter, T. Synthesis 2010, 1804 For recent examples see: (d) Hull, K. L.; Anani, W. Q.; Sanford, M. S. J. Am. Chem. Soc. 2006, 128, 7134; (e) Wang, X.; Mei, T. S.; Yu, J. Q. J. Am. Chem. Soc. 2009, 131, 7520; (f) Furuya, T.; Kaiser, H. M.; Ritter, T. Angew. Chem., Int. Ed. 2008, 47, 5993; (g) Watson, D. A.; Su, M.; Teverovskiy, G.; Zhang, Y.; García-Fortanet, J.; Kinzel, T.; Bulchwald, S. L. Science 2009, 325, 1661; (h) Tang, P.; Furuya, T.; Ritter, T. J. Am. Chem. Soc. 2010, 132, 12150.

[8] Qiu, S.; Xu, T.; Zhou, J.; Guo, Y.; Liu, G. J. Am. Chem. Soc. 2010, $132,2856$.

[9] Wu, T.; Yin, G.; Liu, G. J. Am. Chem. Soc. 2009, 131, 16354.

[10] The effect of silver is unclear at this moment. It is possible that $\mathrm{AgF}$ is effective for the generation of C-PdF complex via the interaction of Ag and Pd. For details, see: (a) Heckenroth, M.; Neels, A.; Garnier, M. G.; Aebi, P.; Ehlers, A. W.; Albrecht, M. Chem. Eur. J. 2009, 15, 9375; (b) Heckenroth, M.; Kluser, E.; Neels, A.; Albrecht, M. Angew. Chem., Int. Ed. 2007, 46, 6293.

[11] (a) Gatti, G.; López, J. A.; Mealli, C.; Musco, A. J. Organomet. Chem. 1994, 483, 77; (b) Rix, F. C.; Brookhart, M.; White, P. S. J Am. Chem. Soc. 1996, 118, 2436; (c) LaPoite, A. M.; Rix, F. C.; Brookhart, M. J. Am. Chem. Soc. 1997, 119, 906; (d) Lin, Y. S.; Yamamoto, A. Organometallics 1998, 17, 3466; (e) Nozaki, K.; Komaki, H.; Kawashima, Y.; Hiyama, T.; Matsubara, T. J. Am. Chem. Soc. 2001, 123, 534; (f) Hii, K. K.; Claridge, T. D. W.; Giernoth, R.; Brown, J. M. Adv. Synth. Catal. 2004, 346, 983.

(Qin, X.) 